\title{
Diversity of plants as a food supplement and medicine for livestock: Local culture in cattleman communities
}

\author{
HARMEN \\ Animal Product Quality Assurance Laboratory, Animal Husbandry, and Animal Health Service of West Sumatra Province. J1. Rasuna Said 68, Padang \\ 25139, Sumatera Barat, Indonesia. Tel./fax.: +62-751-28060, ^email: harmendisnak@ gmail.com
}

Manuscript received: 15 October 2019. Revision accepted: 18 May 2020.

\begin{abstract}
Harmen. 2020. Diversity of plants as a food supplement and medicine for livestock: Local culture in cattleman communities. Asian J Ethnobiol 3: 23-29. Various types of plants can be used as food for livestock. In addition to its function as feed, several types of plants can also be used as medicines for livestock. The research aims to record the types of plant species that farmers traditionally used as feed supplements and medicinal for livestock. Observations were made using a survey method in three regions in West Sumatra, namely Tanah Datar, Solok, and Limapuluh Kota District. Sampling was carried out randomly (random selection) by picking up breeders considered successfully (breeder having more than five cows) and familiar with traditional medicines as a sample. Interviews were conducted to obtain information on the plants used as supplements or medicinal. Furthermore, the plant types were recorded in their location of growing. All kinds of plants were documented in the form of photographs. Data were displayed descriptively, i.e., images with supporting information. The observations found more than 15 types of plants commonly used by cattlemen to increase growth, reproductive capacity, and medicinal if livestock had health problems.
\end{abstract}

Keywords: Livestock, local culture, supplement, plants medicine

\section{INTRODUCTION}

West Sumatra (Indonesia) is an agricultural area with a flat topographical structure and moderately steep slope. The agriculture and animal husbandry sector has been developing in West Sumatra from ancient times, so there is a philosophy in the community, i.e., "Padi Manguniang Jaguang Maupiah Taranak Bakambang biak." This means the community also has livestock breeding for their savings other than growing rice and corn as a food source. That's why agriculture has been a culture of the society in West Sumatra for generations.

West Sumatra has a population of 5.48 million and 255.525 farming houses in the district/city. The populate of large ruminant livestock consists of 393,491 beef cattle and 110,236 buffaloes, while the poultry consists of $9,222,765$ laying breeds, 4,054,846 dual-purpose breeds (non-race chicken), and 26,232,909 meat breeds (broiler/race chicken) (BPS of West Sumatra, 2018). The area of West Sumatra is $42,229.64 \mathrm{~km}^{2}$ with an area of cultivation land of $23,356.85 \mathrm{~km}^{2}$, which strongly supports the development of the livestock sector. Geographically, the location of West Sumatra Province is $0^{\circ} 54^{\prime} \mathrm{NL}-3^{\circ} 30^{\prime} \mathrm{SL}$ and $-98^{\circ} 36^{\prime}$ $\mathrm{WL}-101^{\circ} 53^{\prime} \mathrm{WL}$ with a height of about $2 \mathrm{~m}$ to $2,912 \mathrm{~m}$ asl. Agro-climatically, West Sumatra has a temperate climate with temperatures ranging from 17 to $27 \mathrm{C}$ and high rainfall levels ranging from 1,980 to more than 5,000 mm/year (BMKG 2019).

West Sumatra has many mountains and rivers so that the soil is fertile, and it has the potential for a diverse species of plants. The complete institutional infrastructure in West Sumatra Province supports the acceleration of animal husbandry development. Some supporting infrastructure such as Animal Husbandry and Animal Health Service, Faculty of Animal Husbandry, Snakma, BPPV Bukittinggi, BPTU Padang Mengatas, BPTP Sukarami, Quarantine, Keswan Post, Pus IB, UPTD BIB Tuah Sakato, UPTD Poultry Simpang Empat, RPH, Livestock Market, UPTD Beef Cattle Air Rundiang, Breeder Club. In a forum, these institutions work together in the International Breeding Center for Cattle (IBCfC), West Sumatra. Regarding the Synergy Team of the Faculty of Animal Husbandry of Andalas University study, agricultural land capacity for the development of ruminants in West Sumatra was 3,250,000 animals.

Along with the development progress of animal husbandry, there is a demand that all production costs must be optimized to produce the expected outputs. The high cost of production, mainly commercial feed and medicine, requires other alternatives to overcome the problem. In addition, the increasing public awareness of the importance of food safety can encourage breeders to utilize various plants traditionally used as feed supplements and medicines.

A plant having medicinal properties is one of the alternatives in the supply of feed ingredients with multiple functions. The parts of this plant are used as additional food for the growth and productivity of livestock and as a control of animal health for both poultry and ruminant animals. Some breeders have already used natural ingredients to feed their animals. Therefore it is necessary to record and expand medicinal plants available in the local area. Many plants around the local environment can be used as feed supplements and medicinal for livestock, such as rambutan leaves, areca leaves, katuk leaves, moringa leaves, betel leaves, and hibiscus leaves. The use of this 
plant can be singly, or as a mixture in various forms (powder or concoction), that can be given to poultry and ruminants. Its use is done in multiple ways, including drinking water or mixed feed as supplement food. This local wisdom in the farming community needs to be inventoried.

Based on the above, observations have been made to record and obtain information on plant diversity as feed supplements and medicines for livestock.

\section{MATERIALS AND METHODS}

\section{Observation location}

Sampling and sources of information came from farmers in the Solok District, Tanah Datar District, Limapuluh Kota District of West Sumatra Province, Indonesia, and were conducted from January to August 2019. The map of the observed locations can be seen in the picture below (figure 1). This research uses stationery, a camera, GPS, and a questionnaire.

\section{Methods}

The method used in this observation is a survey method. The survey was conducted to record the types of plants used by farmers by inventorying and interviewing. The interviewed farmers are farmers who have knowledge in the use of plants as medicine for livestock and are usually to using these plants, even from generation to generation. At each location, one farmer was determined to be interviewed. The farmers interviewed were owners of livestock breeding with a minimum of five cows.

Interviews were conducted to obtain information on plant species regularly used as feed ingredients/feed supplements and medicines for livestock, how to process them, and their application to livestock.

\section{Data analysis}

The results of observation were analyzed descriptively and displayed in tables and pictures.

\section{RESULTS AND DISCUSSION}

\section{General description of the observation location}

Plant sampling locations are at an altitude of 500 - 750 $\mathrm{m}$ above sea level. In the sampling area, there are many animal husbandry locations around the valley and the foothills of the three mountains, namely the Merapi, Talang, and Sago. Farmers regularly use plants as supplement food and medicine when the livestock's health got a problem. At the research location, it's common to find breeders who understand these matters. The study area is the center of beef cattle in West Sumatra. A general description of the site can be seen in Table 1 .

\section{Types of plants that are used as feed supplements and medicines for livestock}

The results of interviews with farmers and observations of plant species used as medicinal and supplements for breeders come from the types of trees and shrubs found in the area around the farm. This type of plant has been used for medicinal, both for humans and animals. Plant species are named accordingly to where they are found, which is sometimes different from common Indonesian names (Table 2).

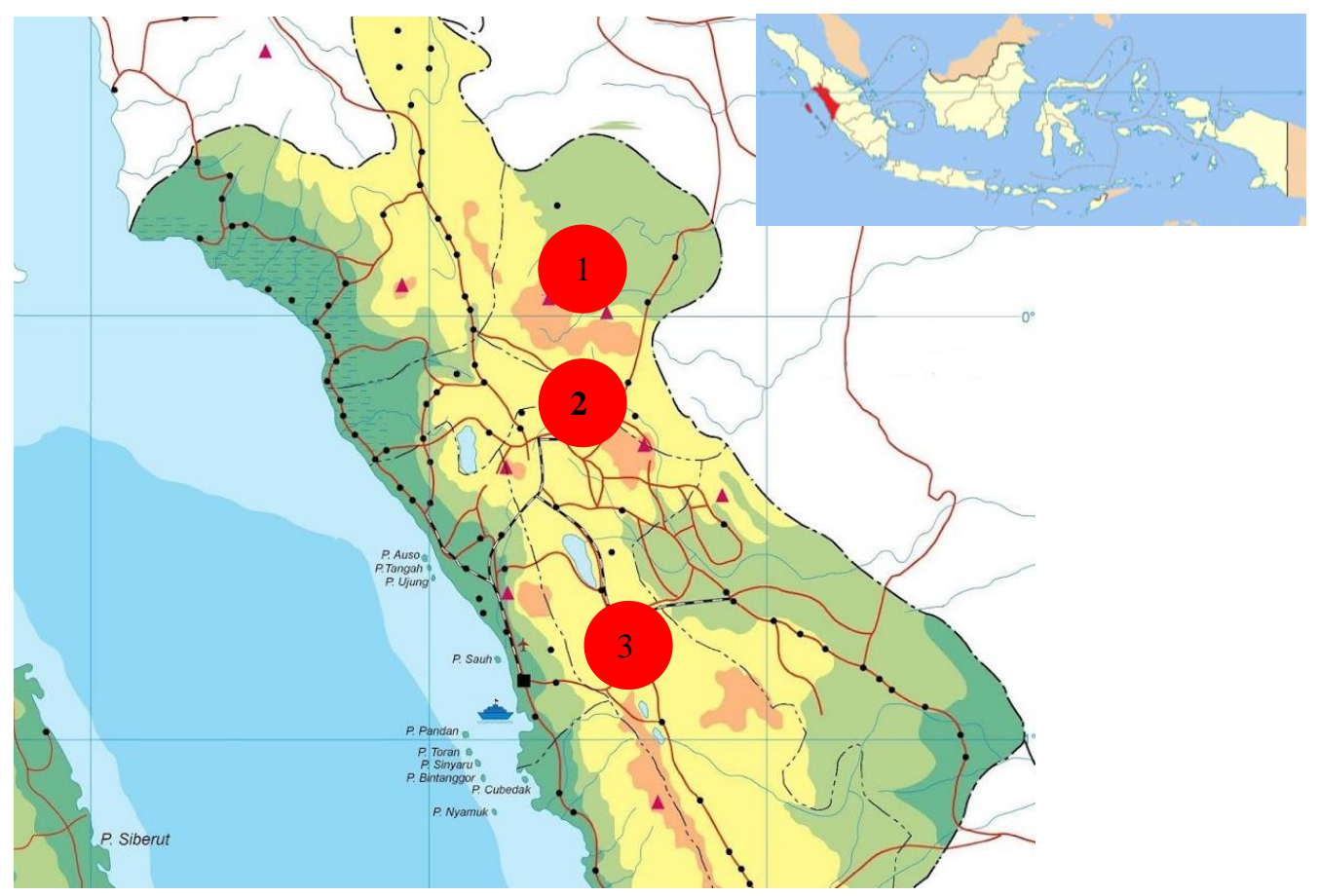

Figure 1. Map of observation location in West Sumatra, Indonesia. 1. Lima Puluh Kota 2. Tanah Datar 3. Solok 
Tabel 1. General description of research locations

\begin{tabular}{lcc}
\hline \multicolumn{1}{c}{ Location } & \multicolumn{2}{c}{ Parameter } \\
\cline { 2 - 3 } & $\begin{array}{c}\text { Altitude } \\
(\mathbf{m} . \text { asl })\end{array}$ & $\begin{array}{c}\text { Location } \\
\text { Coordinates }\end{array}$ \\
\hline $\begin{array}{l}\text { Tanah Datar, } \\
\text { Kecamatan Salimpaung, }\end{array}$ & $750-1000 \mathrm{~m}$ & $0^{\circ} 20^{\prime} 58.8^{\prime \prime} \mathrm{S}$ \\
Nagari Tanjung Lurah & & $100^{\circ} 31^{\prime} 43.9^{\prime \prime} \mathrm{E}$ \\
$\begin{array}{l}\text { Limapuluh Kota, } \\
\text { Kecamatan Lareh Sago Halaban, }\end{array}$ & $450-1000$ & $0^{\circ} 20^{\prime} 16.8^{\prime \prime} \mathrm{S}$ \\
$\begin{array}{l}\text { Nagari Labuah Gunuang } \\
\text { Kabupaten Solok, }\end{array}$ & & $100^{\circ} 42^{\prime} 44.2^{\prime \prime} \mathrm{E}$ \\
Kecamatan Kubung, & $402-420$ & $0^{\circ} 46^{\prime} 20.0^{\prime \prime} \mathrm{S}$ \\
Nagari Saok Laweh & & $100^{\circ} 40 ' 53.2^{\prime \prime} \mathrm{E}$ \\
\hline
\end{tabular}

Table 2. Types of plants used as medicinal materials and feed supplements by farmers

\begin{tabular}{lll}
\hline \multicolumn{1}{c}{ Scientific name } & Indonesian name & $\begin{array}{l}\text { Regional name } \\
\text { (Minang) }\end{array}$ \\
\hline Areca catechu & Pinang & Pinang \\
Moringa oleifera & Kelor & Marunggai \\
Annona muricata & Sirsak & Durian Balando \\
Manilkara zapota & Sawo & Saus \\
Carica papaya & Pepaya & Kaliki \\
Toona Sureni & Suren & Surian \\
Psidium guajava & Jambu biji & Jambu Peraweh \\
Bambuseae spp & Bambu & Batuang \\
Hibiscus Sinensis & Kembang sepatu & Bungo rayo \\
Nephelium lappaceum & Rambutan & Rambutan \\
Gliricidia sepium & Gamal & Dadok medan \\
Curcuma longa & Kunir & Kunyit \\
Citrus aurantifolia & Jeruk nipis & Asam kapeh \\
Piper betel & Sirih & Siriah \\
Tithonia diversifolia. & Daun paitan & Bungo paik \\
\hline
\end{tabular}

From the table, it can be seen that some plants can be used as food, medicine, or supplements for livestock. These plants have their regional names based on the location of the plants found. Generally, all plants were found in all observed areas and were named in the Minang language.

\section{The function and use of plants that farmers use as medicine and food supplements \\ Areca nut (pinang)}

Areca nut tree is a tree-shaped plant and grows in various regions in Indonesia. Its scientific name is Areca catechu (English: Betel palm or Betel nut tree), and it is a type of monocot plant classified as a palm tree. Areca tree belongs to the Arecaceae family in the order Arecales (Heyne 1987). According to the area where it grows or its colors, Areca nut is named according to where it grows, such as Irian areca nut, yellow areca nut, pinang, and others. Pinang also has a different name in each region, such as in Aceh, it is called "pineung"; in Batak/Toba, "pining"; in Sunda or Java, it is called "jambe."

Areca nut has many benefits, especially in the food and energy industries (as biofuel). The use of areca nuts as an ingredient, eaten with piper betel leaf, has become a custom for generations in certain regions in Indonesia, but the consumers are limited. Empirically the seed of the areca nut can overcome various types of diseases. Multiple benefits that can be obtained from the use of kernel of areca nut are as follows: basic need, energy source, and ingredient in traditional ceremonies (i), substitute for cigarettes, digestion regulator, and component to prevent sleepiness (ii), cosmetic and slimming ingredient (iii), ingredient of a standard drug (iv), and antidepressant (v) (Barlina 2007).

Almost all parts of areca nut plants can be used. The functions and benefits of areca nut differ according to their intended use. Areca nuts can be used as ingredients by breeders for their livestock, such as poultry and large animals or ruminants. Ruminant breeders, for example, have used young areca leaves and ripe areca nuts as medicines for cattle (Figure 2).

Breeders assume that areca nuts are helpful as an energy booster for their livestock. Breeders provide areca nut concoctions with other ingredients for cattle that have just given birth. Breeders offer cattle that have just given birth to this herb to accelerate the release of the placenta.

Use areca nut by processing and adding it with other materials or plants, such as bamboo leaves, honey, duck eggs, and water. While the leaf part is used, it means the young areca nut leaves. This leaf mixture was added with bamboo leaves, one duck egg, two tablespoons of honey, and $1 / 2$ liter of water. This mixture is blended with a blender; then, it is given to cattle.

Another areca nut beneficial to livestock is the ripe areca nut (Figure 2. B). The processed ripe betel nut is used as a tapeworm medicine (Taenia saginata) and liver worms (Fasciola gigantica). To use it, some mature betel seeds are ground into areca nut powder mixed with piladang leaves (Solenostemon scutellarioides (L.) Codd) sufficiently and added with $1 / 2$ liter of water. After that, the mixture is squeezed, and the concoction is given to the cattle three times a day, starting in the morning.

There are so many benefits of areca nut that humans can take. The processing of ripe fruit is also a source of income for farmers. Ripe fruit is taken seeds, dried, and then marketed (Kristina et al. 2007).

\section{Moringa}

Moringa is a type of plant from the Moringaceae tribe, with its scientific name Moringa oleifera. This plant tallincrease, live long, bloom throughout the year, and withstand extreme heat conditions. Moringa is a shrub that can have a trunk with a height of 7 -11 m (Amzu 2014).

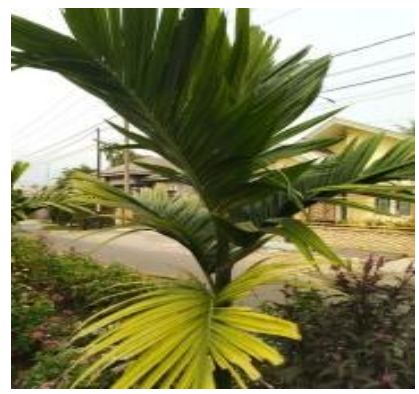

A

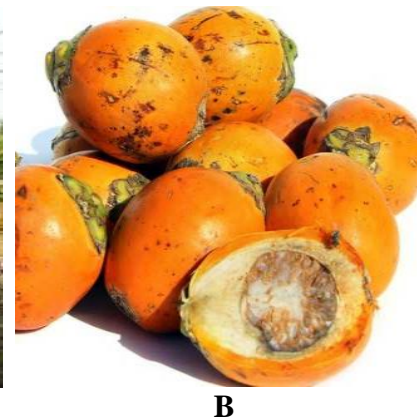

B
Figure 2. Areca palm (A) and ripe betel nut (B) 
In West Sumatra, the moringa tree is called merunggai, which is usually planted as a border plant for hedge and yard and has medicinal properties. The Marunggai tree's trunk is not so big. The wood trunk is brittle (easily broken), and its branches are rare but have strong roots. The leaves are oval-shaped with small sizes arranged compound in a single stalk.

In human life, the moringa tree is beneficial. This tree has many benefits for humans as herbal medicine, which is considered could overcome various types of diseases, including cancer (Mardiana et al., 2012). From the results of the analysis of nutrient content, it can be seen that the merunggai leaf has outstanding potential to complement the nutritional needs of the body. By consuming merunggai leaves, the healthy balance in the body will be fulfilled. Human consuming merunggai leaves will be helped to increase their energy and endurance. In addition, merunggai leaf is also efficacious to overcome the various complaints caused by lack of vitamins and minerals, such as vitamin A deficiency (visual impairment) and Choline deficiency (accumulation of fat in the liver) (Amina et al. 2015).

As for livestock, Moringa can be used as high-quality feed ingredients with complete nutritional content and efficaciously as medicinal such as improved reproduction of animals, treating malaria, supplementary feeds, and others. Based on the experience of breeders, almost all parts of Moringa plants can be used as nutritious and medicinal feed for ruminants. Young leaves and twigs/leaf stems can be used as a feed supplement in the ration because they contain high nutritional elements. Even moringa leaves can be used as a substitute for Starbio in the manufacture of fermented feed. Moringa leaves for meals are usually added by several other elements such as paitan grass leaves, Gamal leaves, lamtoro leaves, rumen contents, bran, and molasses, as shown in Figure 3.

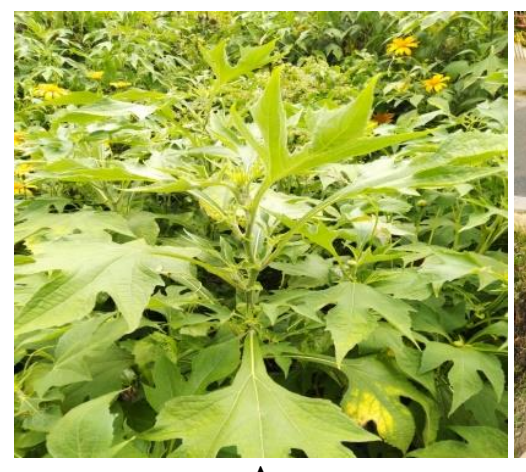

A

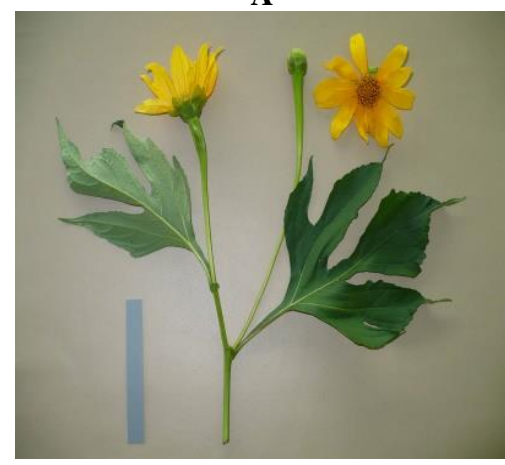

D

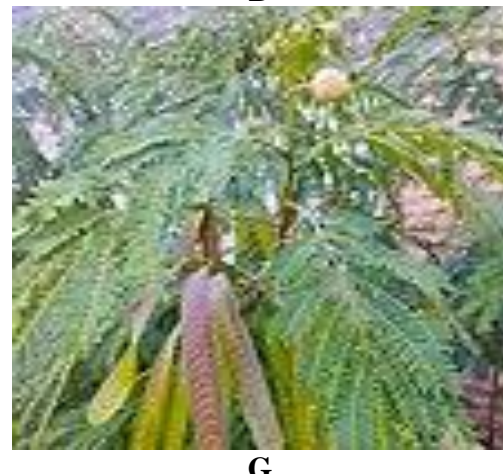

G

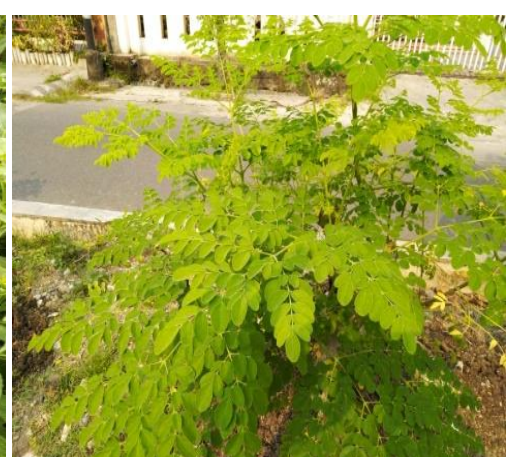

B

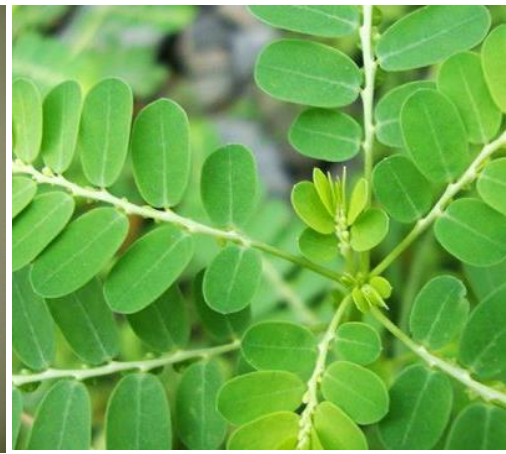

$\mathbf{E}$

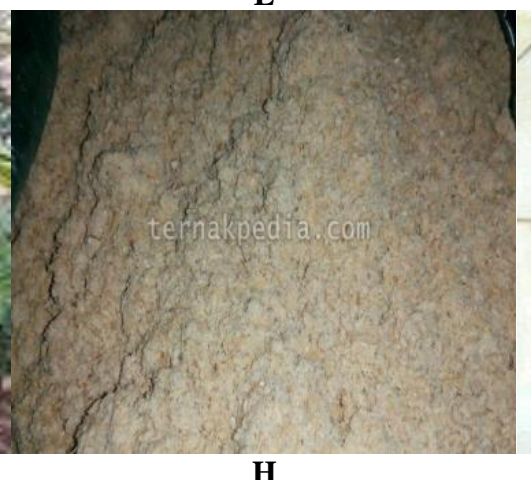

H

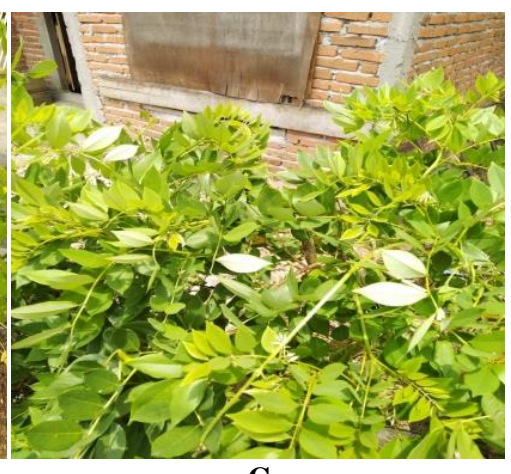

C

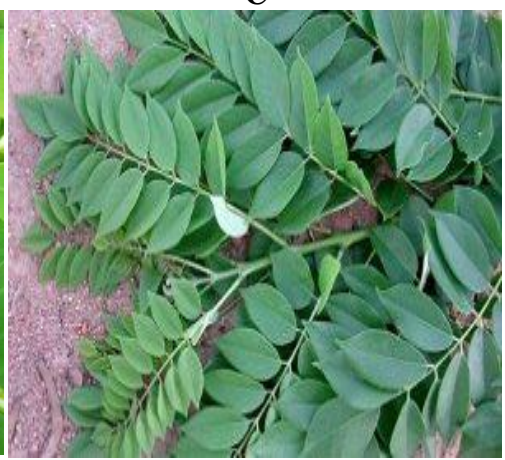

F

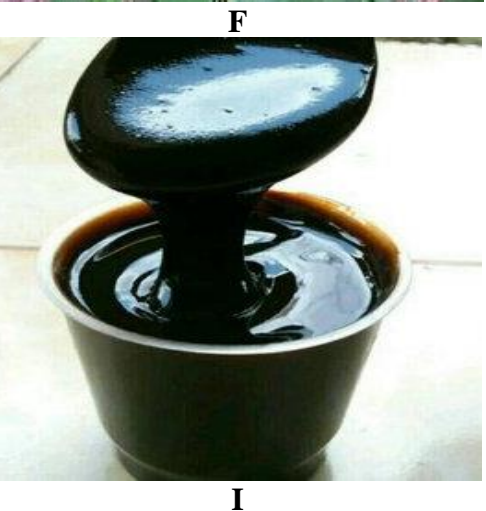

Figure 3. A. Paitan flower tree, B. Marunggai/Moringa tree, C. Gamal tree, D. Paitan leaf stalk, E. Marunggai tree shoot, F. Gamal leaf stalk, G. Lamtoro,H. Bran, I. Molases 


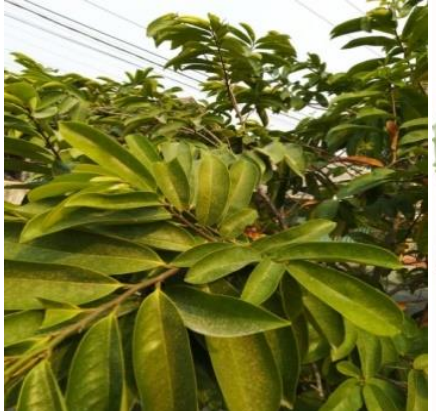

A

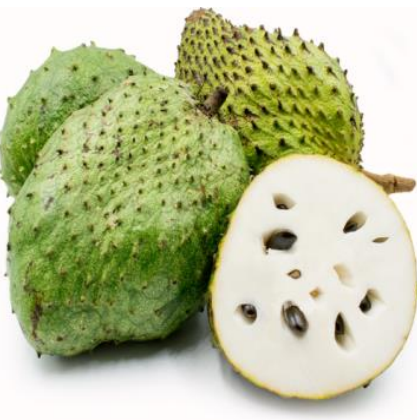

$\mathbf{B}$

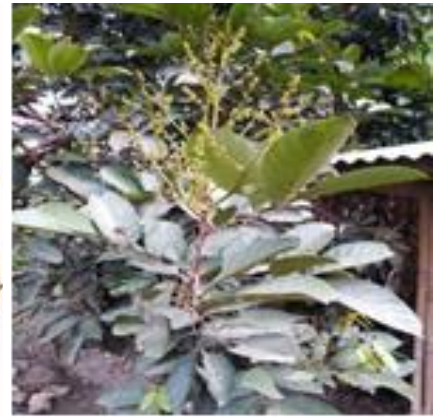

$\mathbf{C}$

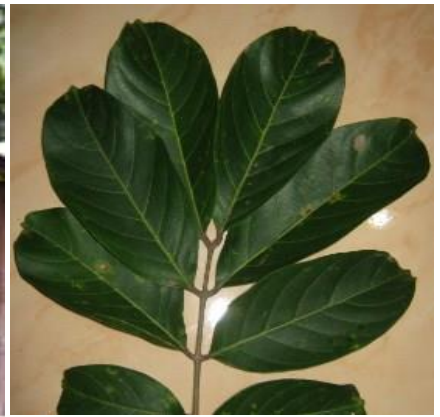

D

Figure 4. A. Soursop tree, B. Soursop fruit, C. Rambutan tree, D. Rambutan leaves

Moringa leaves and other ingredients are dried in the sun and made into a powder to make fermented feed. Mix the powder ingredients with bran plus Starbio, molasses and then dry them all, and at last, they are all ready to be used/utilized. As a probiotic in straw fermentation, $2 \mathrm{~kg}$ of the mixture can be added into 1 ton of feed. This mixture can also prevent and treat malaria, intestinal worms, bloating, decreased appetite, and reproductive disorders in cattle.

\section{Soursop}

Soursop's scientific name is Annona muricata L, and it is commonly called Durian balando in the area of West Sumatra. Soursop is a valuable plant originating from the Caribbean, Central America, and South America. In Indonesia, soursop can grow well at $1000 \mathrm{~m}$ above sea level. Soursop trees can reach a height of $9 \mathrm{~m}$.

Soursop fruit is widely consumed and used for treatment. In soursop leaves, there can be found acetogenin compounds helpful in treating various diseases (Puspitasari 2016). An excellent benefit for the health and treatment of livestock is to reduce the body temperature of animals. Then it can also be utilized as a calming agent, especially for cattle that have just traveled or are recently moved from specific places/locations.

The way to use soursop leaves as a medicine for reducing the body temperature of cattle is by adding 1 ounce of rambutan leaves (Figure 4) into 1 ounce of soursop leaves and then adding them with 3 ounces of palm sugar and $1 / 2$ liter of water. Give the concoction to the cattle.

\section{Turmeric}

Turmeric is a native plant of Southeast Asia and has its scientific name of Curcuma domestica Val. It is one of the Zingiberaceae plants widely planted in woods and gardens. The word Curcuma is derived from the Arabic Corkum, which means yellow (Winarto 2005). This plant is widely grown or cultivated as a supplement to herbs or medicinal herbs; However, it is considered traditional, but turmeric has been studied in the laboratory globally to determine the content of substances and their effects on health (Ghofur et al. 2016).

Turmeric adds a bright or reddish yellow color to the yolk in animal husbandry. When mixed into the chicken ration, turmeric can eliminate the smell of chicken excrement and increase chicken weight (Said 2001). Turmeric parts used to increase appetite and flatulence in cattle are the rhizome.

The way to use it is by processing turmeric rhizome into powder and then adding other ingredients such as lime juice and one duck egg then blended with a blender. The mixture is given to cattle before breakfast for three days.

\section{Hibiscus.}

In Indonesian, this flower is called kembang sepatu, with the scientific name of Hibiscus rosa-sinensis. Hibiscus leaves (Figure 6. A) are used to reduce body heat, a symptom of fever in humans and livestock. It also smoothens the process of birth and fetal growth in the uterus for livestock. Sweet potato leaves are usually added to hibiscus (Figure 6. C) and water derived from burned kalek banana midrib as a medicinal content (Figure 6. B).

To prepare those medicinal herbs is as follows: the stem of the kalek banana is burned and squeezed to take water out. The water is collected in a pail. Hibiscus leaves and sweet potato leaves are added to the water then pressed. This water is given to the livestock as a drink, and the pulp is given to livestock as food.

\section{Guava}

The Guava plant's Latin name is Psidium guajava, better known as jambu paraweh (Minang language). It can flourish in low areas up to $1200 \mathrm{~m}$ above sea level, but it cannot grow well in a too hot or too cold area. The size of this plant reaches 3-10 m (Mursito 2002). Traditionally, all parts of this plant are beneficial and have medicinal properties such as the leaves, the stems, the fruit flesh, and the roots. To compare, Ethanol extract of guava white fruit flesh has a more vigorous activity against Salmonella typhi than ethanol extract of red guava fruit flesh. Thus ethanol extract of guava white fruit flesh could be more effective for treating diarrhea caused by $S$. typhi bacteria (Adnyana et al. 2004).

Some symptoms of disease in cattle are treated with this guava. Breeders use this plant to treat cattle suffering from indigestion with symptoms of diarrhea.

The simple use of this fruit is as follows: the bark, the leaves, the fruit flesh, and the roots added by fruit sauce/sapodilla and salt. It is crushed/chopped and then is boiled. This mixture is drunk on sick cattle. 


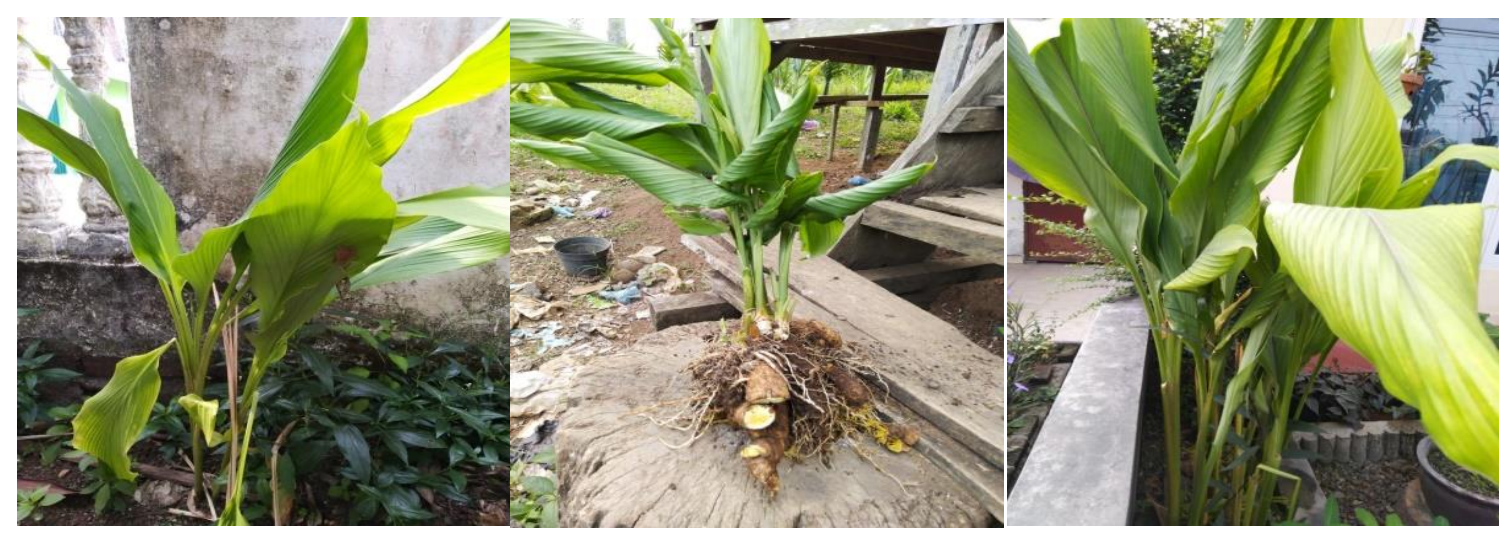

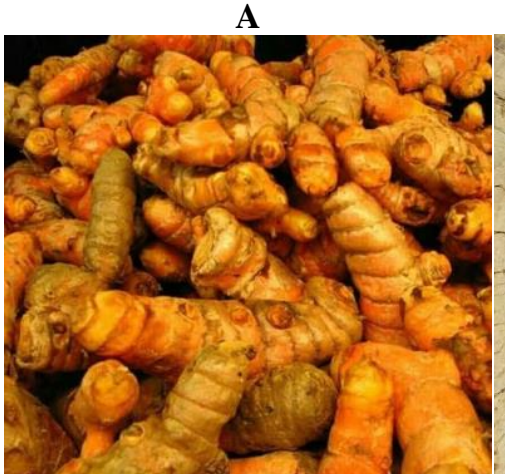

D
B

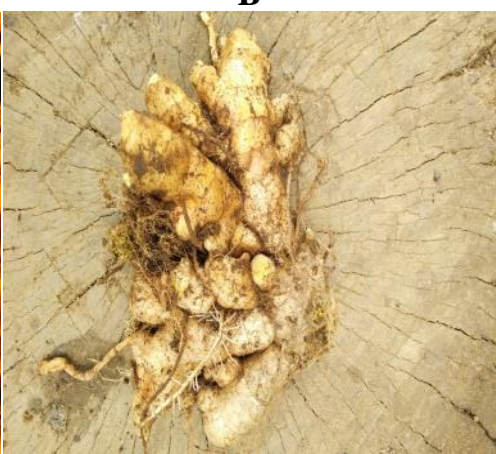

$\mathbf{E}$
C

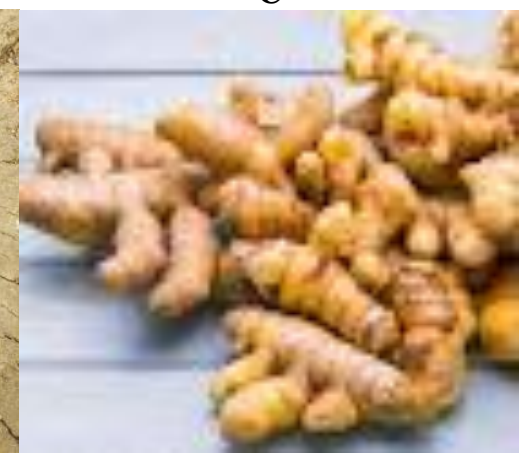

$\mathbf{F}$

Figure 5. A. Ordinary turmeric plants, B. White turmeric, C. Charcoal turmeric, D. Rhizomes of ordinary turmeric plants, E. Rhizomes of white turmeric, F. Rhizomes of charcoal turmeric (Private collection 2019; Rafikasari 2019)

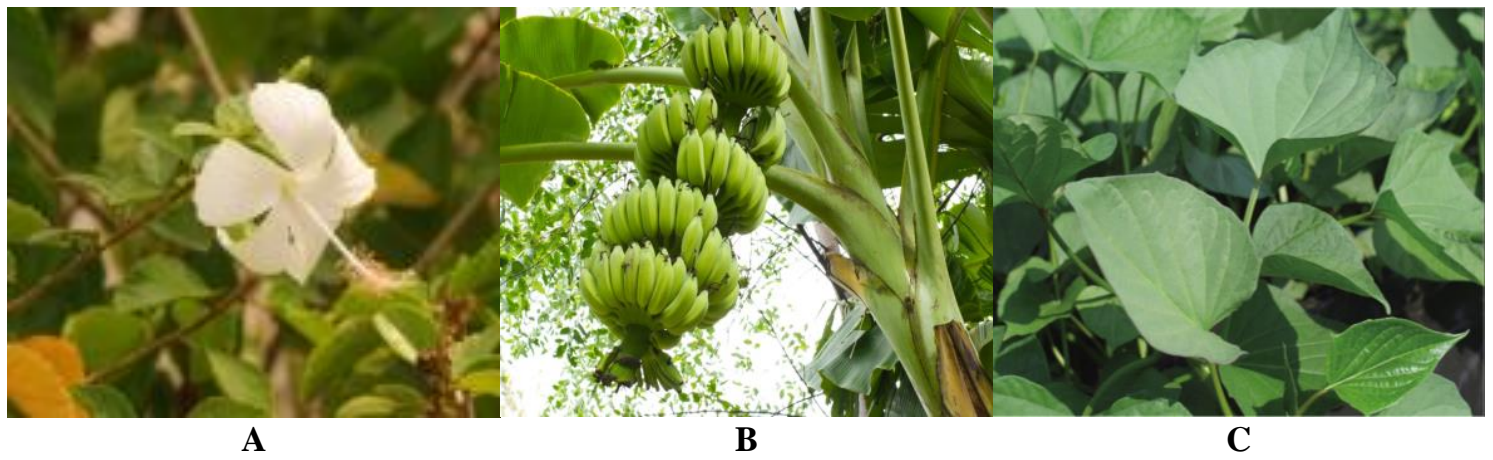

Figure 6. A. Hibiscus, B. Kalek banana, C. Sweet potato leaves

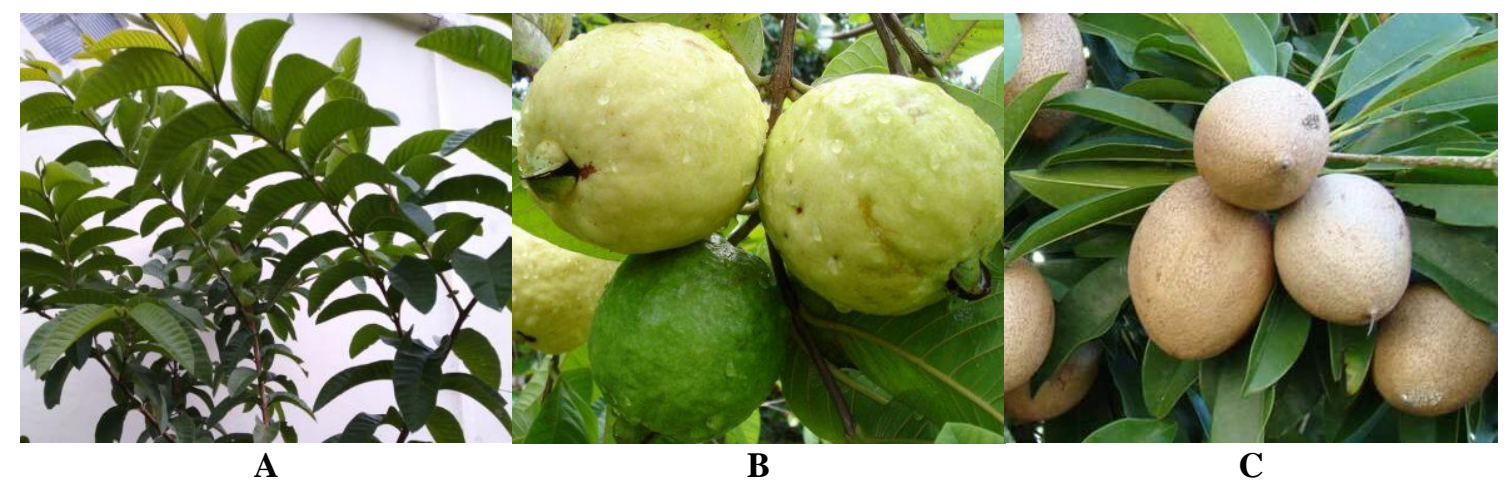

Figure 7. A. Guava tree, B. Guava fruit, C. Sapodilla 


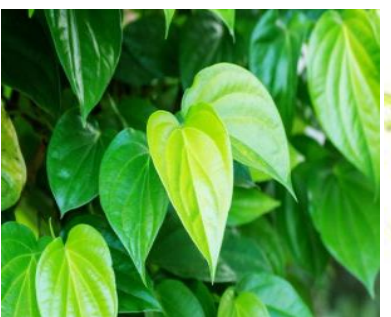

A

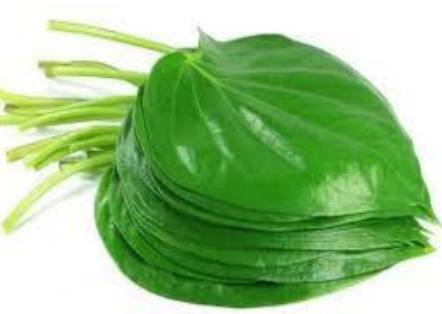

B
Figure 8. A. Betel plants, B. Betel leaves

Betel

Betel is a native plant of Indonesia with its scientific name of Piper betle. It grows by creeping or leaning against other tree trunks (Mursito 2002). Betel leaf is known for its antiseptic, anti-inflammatory, and skin conditioning properties. For humans, its benefits are not only for the outer part of the body but also for the inner part of the human, such as the health of digestive and reproductive organs. Betel leaf is one of the herbal leaves with many benefits that humans can utilize. The properties of the leaves are most famous for their cleansing properties in humans (Soedibjo 1992).

Besides that, breeders also use betel leaves as cough medicine and influenza for livestock. Preparing it as follows: pick 21 pieces of betel leaf (Figure 8. B) and place it, then add one tablespoon of lump sugar, add $1 / 2$ liter of water and boil them. The boiled water with the betel leaf is drunk on cattle.

The interviews and observations found that 15 plants can be used as animal feed and medicines. Breeders use plant materials to increase livestock growth, reproductive capacity, and treatment for livestock with health problems. Plants are used singly or in the form of a mixture of herbs.

\section{REFERENCES}

Adnyana IK, Elin Yulinah, Joseph IS, Neng FK., Muhamad I. 2004. Efek ekstrak daun jambu biji daging buah putih dan jambu biji daging buah merah sebagai antidiare. Acta Pharmaceutica Indonesia 29 (1): 19-27. [Indonesian]

Amina S, Tezar R, Miflihani Y. 2015. Kandungan nutrisi dan sifat fungsional tanaman kelor (Moringa oleifera). Buletin Pertanian Perkotaan 5 (2): 35-44. [Indonesian]

Amzu E. 2014. Kampung konservasi kelor: upaya mendukung gerakan nasional sadar gizi dan mengatasi malnutrisi di Indonesia. Risalah Kebijakan Pertanian Lingkungan 1 (2): 86-91. DOI: 10.20957/jkebijakan.v1i2.10298. [Indonesian]

Badan Meteorologi Klimatologi dan Geofisika Klimat Sicincin. 2019. Data Curah hujan di daerah Sumatera Barat. BMKG, Jakarta. [Indonesian]

Badan Pusat Statistik Sumbar. 2018. Sumatera Barat dalam Angka: Data populasi ternak di Sumatera Barat-2018, BPS Provinsi Sumatera Barat, Padang. [Indonesian]

Barlina R. 2007. Peluang pemanfaatan buah pinang untuk pangan. Buletin Palma 33: 96-105. [Indonesian]

Ghofur M, Sugihartono M, Arfah J. 2016. Uji efektifitas ekstrak kunyit (Curcuma domestical) terhadap daya tetas telur ikan gurami (Osphronemus gouramy Lac.). Jurnal Ilmiah Universitas Batanghari Jambi 16 (10): 68-76. [Indonesian]

Heyne K. 1987. Tumbuhan Berguna Indonesia jilid 1. Yay Sarana Wana Jaya, Jakarta. [Indonesian]

Kristina NN, Syahid SF, 2007. Penggunaan Tanaman Kelapa (Cocos nucifera), Pinang (Areca catechu) dan Aren (Arenga pinnata) sebagai Tanaman Obat. Balittro, Bogor. [Indonesian]

Mardiana. L, 2012. Daun Ajaib Tumpas Penyakit. Penebar Swadaya, Jakarta. [Indonesian]

Mursito B, Heru P. 2011. Tanaman Hias Berkhasiat Obat. Penebar Swadaya, Jakarta. [Indonesian]

Puspitasari M, Tara VW, Tri DW, Jaya MM, Nur IPN.2016. Aktivitas antioksidan suplemen herbal daun sirsak (Annona muricata L.) dan kulit manggis (Garcinia mangostana L.): Kajian pustaka. Jurnal Pangan dan Agroindustri 4 (1): 283-290. [Indonesian]

Rafikasari D. 2019. Kunyit membantu mengobati depresi, Koran Sindonews. https://lifestyle.sindonews.com /read/1444217/155/ kunyit-membantu-mengobati-depresi-1569822730. [20 Januari 2020]. [Indonesian]

Soedibjo M. 1992. Manfaat sirih dalam perawatan kesehatan dan kecantikan. Warta Tumbuhan Obat Indonesia 1 (1). [Indonesian]

Said.A, 2001. Khasiat dan Manfaat Kunyit. PT. Sinar Wadja Lestari, Jakarta. [Indonesian]

Winarto WP. 2005. Khasiat dan Manfaat Kunyit. Agromedia Pustaka, Jakarta. [Indonesian] 